\title{
Dinamika Kebijakan Perencanaan Pembangunan Nasional Indonesia
}

\author{
Ade Reza Hariyadi ${ }^{1}$ \\ ${ }^{1}$ Magister Ilmu Administrasi Krisnadwipayana Jakarta \\ Jalan Raya Jatiwaringin, RT. 03 / RW. 04, Jatiwaringin, Pondok Gede, RT.009/RW.005, \\ Jaticempaka, Kec. Pondokgede, Kota Bks, Jawa Barat 13077
}

\begin{abstract}
This paper describes how the evolution of national development planning policies in Indonesia is mainly related to the philosophical, political and economic framework factors that influence it, as well as how the challenges and policy scenarios that can be taken in responding to the issue of amendments to the 1945 Constitution to establish the State Policy Guidelines as national development guidelines. The analysis found that changes in the national development planning policy model were driven by a number of factors such as the mainstream and the state's political direction, the configuration of existing political power and the dominant economic mainstream at that time. These factors not only affect the national development planning policy model, but also become a challenge in the planning and implementation of national development in Indonesia.
\end{abstract}

Keywords: Dynamic, Development, Planning, Bappenas

\section{Pendahuluan}

Kebijakan

perencanaan

pembangunan nasional diadopsi oleh berbagai negara dengan beragam model dan area yang menjadi lingkup kewenangan negara. Sejauhmana derajat keterlibatan atau intervensi pemerintahan dalam pembangunan, terutama masalah-masalah ekonomi inilah yang biasanya menjadi karakteristik yang membedakan antara negara berkembang dan negara maju. Menurut Huff (1995), negara berkembang biasanya dicirikan dengan lemahnya konsensus politik dan luasnya arena keterlibatan pemerintahan dalam masalah-masalah pembangunan ekonomi. Namun, situasi ini rupanya mengalami perubahan dimana negara-negara maju memperlihatkan kecenderungan pemerintahan yang semakin intensif dalam masalahmasalah pembangunan yang pada umumnya lekat dengan peran aktif dari pada pasar. Hal tersebut setidaknya dapat diamati dari fenomena di Amerika Serikat dalam rentang dua dekade ini ditandai dengan semakin aktifnya peran negara-negara bagian dalam perencanaan pembangunan, terutama menyangkut kepentingan perdagangan dan perumbuhan ekonomi, pembangunan infrastruktur, riset dan pengembangan serta mengintegrasikan pengetahuan 259

*)Corresponding Author

Email : rezahariyadi@yahoo.com 
dengan bisnis dan pasar (Isseman, 1993).

Pengalaman di Indonesia, isu tentang kebijakan pembangunan nasional mengemuka kembali dan dilekatkan dengan agenda politik amandemen ke 5 Undang-Undang Dasar 1945 (UUD NRI) untuk menambah kewenangan MPR dalam menetapkan Pokok Haluan Negara atau sering disebut sebagai GarisGaris Besar Haluan Negara (GBHN). Melalui amandemen terbatas, MPR bermaksud menambahkaan satu ayat pada Pasal 3 untuk memberi kewenangan MPR mengubah dan menetapkan PPHN, serta penambahan satu ayat pada Pasal 23 untuk mengatur kewenangan DPR menolak RUU APBN yang diajukan oleh presiden apabila tidak sesuai dengan PPHN (Kompas Online, 2021). Frasa amandemen terbatas merujuk pada komitmen faksi-faksi di MPR agar amandemen ke 5 UUD NRI tidak meluas pada pasal-pasal lain mengingat saat ini muncul wacana perubahan Pasal 7 UUD NRI untuk menambah masa jabatan presiden menjadi 3 periode dan memperkuat kewenangan DPD, terutama fungsi legislasi dan penganggaran sebagaimana yang dimiliki oleh DPR.

Sesungguhnya, sepanjang sejarah Republik Indonesia pembangunan nasional telah berjalan dan memiliki landasan kebijakan yang berkembang sejalan dengan dinamika politik dari satu periode kekuasaan ke periode kekuasaan yang lain. Namun, landasan kebijakan yang ada saat ini dianggap kurang memadai sehingga mendorong munculnya gagasan untuk mengembalikan konsep pembangunan nasional dalam kerangka yang disebut sebagai Pokok Haluan Negara (PHN) atau khalayak sering menyebut sebagai GBHN.
Pandangan kritis terhadap kebijakan perencanaan pembangunan nasional telah menghadirkan dua arus opini pro dan kontra. Megawati Soekarnoputri menilai bahwa pembangunan nasional terlalu presiden sentris karena tergantung visi dan misi presiden terpilih, serta tidak berkesinambungan akibat pembatasan masa periode jabatan kepresidenan. Menurutnya, perlu konsep pembangunan nasional jangka panjang, baik itu di bidang politik, ekonomi, sosial, pendidikan, kebudayaan maupun spiritual sebagai acuan bagi setiap calon pemimpin yang akan maju dalam kontestasi politik (Kompas Online, 2021).

Sementara itu, Jimly Asshiddiqie, mantan Hakim Mahkamah Konstitusi yang kini menjadi anggota DPD RI menyatakan bahwa pemerintah memerlukan GBHN untuk menghadapi kompleksitas permasalahan seperti kemajemukan suku, pemerataan pembangunan pendidikan, ekonomi, sosial dan kerumitan birokrasi. Menghidupkan kembali GBHN dapat menjadi suatu acuan bagi pembangunan nasional yang berkesinambungan serta visi jangka panjang yang mengintegrasikan pembangunan pusat dan daerah (Vivanews Online, 2021). Kritik tersebut menjadi justifikasi politik untuk menghidupkan kembali Garis Besar Haluan Negara (GBHN) sebagai politik hukum dalam bidang pembangunan nasional yang sistematis dan terencana melalui amandemen UUD 1945 secara terbatas.

Pandangan sebaliknya yang kontra terhadap ide menghidupkan kembali GBHN diutarakan oleh Bivitri Susanti. Menurutnnya, ide tentang GBHN selain tidak relevan dengan 
sistem ketatanegaraan yang telah dipraktekkan sebagai konsekuensi amandemen UUD 1945 selama 4 kali, juga karena telah adanya haluan pembangunan nasional yang lebih partisipatif sebagaimana diatur dalam UU No. 25 Tahun 2004 tentang Sistem Perencanaan Pembangunan Nasional (SPPN) dan UU No.17 Tahun 2007 tentang Rencana Pembangunan Jangka Panjang Nasional (RPJPN) (Hukum Online, 2021). Argumentasi Bivitri Susanti ini juga sejalan dengan pandangan Akbar Tandjung maupun Fahri Hamzah yang melihat bahwa secara substantif maupun dalam kerangka regulasi yang ada (SPPN dan RPJPN) telah berfungsi sebagai pijakan dalam kebijakan perencanaan nasional yang diperlukan (Tirto Online, 2021).

Polemik tentang GBHN menunjukkan dua hal penting, pertama anggapan bahwa keberadaan UU SPPN dan UU RPJPN tidak mencukupi untuk berfungsi sebagai pedoman dalam pembangunan nasional dengan merujuk konsep yang sebelumnya diadopsi dalam GBHN; kedua, bahwa UU SPPN dan RPJPN dianggap tidak memberi jaminan terhadap kesinambungan dan integrasi perencanaan pembangunan antar sektor dan lembaga. Kedua anggapan inilah yang kemudian menjadi basis argumentasi untuk mendorong amandemen ke 5 UUD NRI dengan maksud menghidupkan kembali konsep tentang Haluan Negara. Oleh karena itu, menarik untuk menulis tentang bagaimana dinamika dalam kebijakan perencanaan pembangunan nasional di Indonesia ? Apa tantangan dalam pelaksanaanya ? Skenario kebijakan apa yang dapat dipilih jika amandemen ke V UUD NRI dilangsungkan?

\section{Metode Penelitian}

Penulisan artikel ini dilakukan dengan metode analisis deskriptif dengan pengumpulan data dilakukan dengan cara studi pustaka (library research) dan dokumen.

\section{Hasil dan Pembahasan \\ Perencanaan Pembangunan}

Pembangunan nasional dapat dimaknai sebagai agenda state building yang teah berlangsung pasca kemerdekaan. Hal tersebut diwujudkan melalui pelaksanaan fungsi utama negara, yakni fungsi regular (regular function) yang meliputi fungsi politik, diplomatik, yuridis, administratif, serta fungsi pembangunan (developing function) yang dimaksudkan sebagai suatu perubahan terencana secara terus menerus guna mencapai kondisi perbaikan yang telah ditetapkan (Budiarjo, 2007). Menurut Meyer (2019), pelaksanaan fungsi-fungsi negara ini dalam kerangka mencapai tujuan utama negara, yakni mewujudkan kesejahteraan masyarakat secara merata.

Pembangunan nasional sebagai elemen penting dalam state building tentu saja harus dipahami sebagai peristiwa yang kompleks yang memerlukan suatu perencanaan dimana pemerintah memiliki peranan sentral didalamnya. Patsy Healey (1997) menjelaskan bahwa perencanaan pembangunan di negara maju menekankan pada tiga pendekatan utama, yakni perencanaan ekonomi, manajemen pembangunan fisik, serta manajemen administrasi publik dan analisis kebijakan. Hal tersebut menunjukkan bahwa secara teoritis, studi perencanaan pembangunan merupakan suatu studi yang bersifat multidisiplin dan dapat menghasilkan 
berbagai fokus kajian yang berbeda dan saling mempengaruhi. Meski demikian, secara empiris pendekatan ekonomi dalam kebijakan perencanaan pembangunan di Indonesia menempati posisi sentral.

Pembangunan nasional dimaknai sebagai pembangunan ekonomi dimana upaya untuk meningkatkan pertumbuhan ekonomi menjadi perhatian utama. Sehingga dapat dipahami jika tulisan para ekonom yang mengulas tentang pembangunan seperti Harrod Domar, Arthur Lewis, W W Rostow, Hirschman, Rosenstein Rodan, Nurkse, dan Leibenstein banyak memberikan pengaruh pada para teknokrat perencana pembangunan di Indonesia. Pemikiran dan pengalaman Eropa kemudian menjadi dasar dari konsep dan strategi pembangunan di negara berkembang, termasuk Indonesia. Fenomena inilah yang oleh Bjorn Hettne (1991) disebut dengan eurocentrisme dalam pemikiran awal tentang pembangunan.

Pengaruh nyata dari pemikiran Barat dalam kebijakan pembangunan di Indonesia dapat ditelusuri dalam konsep pembangunan yang diadopsi semasa Orde Baru. Pemikiran Rostow tentang Tahap-Tahap Pertumbuhan Ekonomi memberikan pengaruh besar terhadap kerangka konseptual para perencana pembangunan dalam menyusun strategi pembangunan nasional jangka panjang. Menurut Rostow (1963: 4-16) untuk mencapai kemajuan suatu negara perlu mengadopsi tahapan perkembangan masyarakat yang secara linier harus dilalui, yakni traditional society (masyarakat tradisional), preconditions for take-off (prakondisi menuju tinggal landas), take-off (tinggal landas), drive to maturity (menuju kedewasaan), and age of high mass consumption (masyarakat konsumsi tinggi).

Menurut Rostow, bahwa untuk mencapai taraf kemajuan, transformasi masyarakat perlu dilakukan dengan melakukan modernisasi teknologi dimana corak masyarakat tradisional berbasis agraris dengan pendapatan rendah akan bergerak menuju masyarakat industri dengan peningkatan pendapatan. Memang, pemikiran Rostow ini banyak menuai kritik karena dianggap mensimplifikasi tahapan perkembangan masyarakat secara linier dan gagal untuk menyajikan emipirisme tentang bagaimana pertumbuhan ekonomi itu dapat dipastikan menghasilkan efek cucuran atau trickle down effect sehingga ada pemerataan ekonomi, namun Rostow sebenarnya juga telah menjelaskan adanya faktor lain yang saling berkaitan mempengaruhi pertumbuhan ekonomi seperti kehidupan politik dan hubungan sosial yang berlangsung dalam masyarakat.

Seperti halnya Rostow yang melihat bahwa faktor non ekonomi akan berhubungan dengan strategi pembangunan nasional yang diadosi oleh suatu negara, pemikir lain yang berpengaruh terhadap perkembangan perencanaan pembangunan adalah William Arthur Lewis (1951) yang menulis tentang The Principles of Economic Planning; A Study Prepare for Fabian Society. Menurutnya, perencanaan sebagai upaya pemerintah untuk mewujudkan target yang telah ditetapkan secara teratur dan konsisten melalui proses anggaran yang saling terkait. Perencanaan pembangunan akan berisi ribuan detil yang harus disatukan dan 
menghasilkan ribuan keputusan dan perintah administratif. Kerumitan itulah yang menurut Lewis (1951:11) menempatkan para birokrat sekaligus sebagai perencana, bukan oleh masyarakat, parlemen atau bahkan kabinet, dan membuat perencanaan sering kali dianggap kurang demokratis. Berbagai faktor akan mempengaruhi perencanaan pembangunan nasional suatu negara, seperti kerangka filosofi mengenai bagaimana pembangunan itu berlangsung, aplikasi ekonomi dan proses kompromi politik (Lewis, 1951:11).

Pengaruh faktor mainstream politik maupun ekonomi secara diuraikan oleh Lewis dalam penjelasannya tentang perdebatan antara model perencanaan dengan menekankan peranan sentral negara sebagaimana dianut oleh kaum sosialis dan determinasi mekanisme pasar sebagaimana diyakini pendukung laisser-faire. Lewis (1951 : 12-13) melihat bahwa pokok permasalahan di antara keduanya terletak pada bagaimana memandang soal derajat keterlibatan atau kendali "the invisible" sebagaimana kritik terhadap laisser-faire dan "the visible" dalam hal ini campur tangan negara sebagaimana kritik terhadap model sosialisme atas produksi dan distribusi. Menurutnya, sosialisme memiliki tantangan untuk menjawab masalah tentang hak kepemilikan sebagai fondasi dari kesetaraan dan keadilan sosial, sedangkan mekanisme pasar dihadapkan pada isu tentang ketidakadilan dalam distribusi pendapatan dan masalah pengupahan yang tidak manusiawi. Oleh karena itu, Lewis (1951) menyimpulkan bahwa kerangka kebijakan perencanaan pembangunan semestinya berfokus pada bagaimana membuat apa yang paling dibutuhkan masyarakat menjadi apa yang paling menguntungkan bagi individu, mengubah kepentingan pribadi menjadi kepentingan publik. Selain itu, meski pembangunan ekonomi benar-benar direncanakan dari pusat, maka insentif perlu diadakan. Dengan demikian, perselisihan melawan ekonomi pasar bukan karena tidak cenderung mempromosikan kebaikan sosial. Perselisihannya terletak pada apakah kontrol yang dimiliki negara tidak bisa berbuat lebih baik, baik sebagai alternatif, atau sebagai suplemen (Lewis, 1951:8).

Kerangka konseptual yang mempengaruhi suatu perencanaan pembangunan pada akhirnya ketika diratifikasi menjadi kebijakan maka akan melalui serangkaian proses pembentukan suatu produk hukum sebelum difungsikan sebagai pedoman dalam pembangunan nasional suatu negara. Dalam pengalaman Indonesia, kebijakan perencanaan pembangunan nasional diratifikasi dalam produk hukum berupa Ketetapan MPR sebagaimana model GBHN dimasa Orde Baru, dan SPPN/RPJPN yang dinyatakan dalam bentuk UU. Baik Ketetapan MPR maupun UU merupakan produk hukum yang dihasilkan dari proses politik. Daniel S. Lev (1990), dalam pandangannya tentang hubungan antara hukum dan politik menjelaskan bahwa hukum merupakan alat politik, tempat hukum dalam negara tergantung pada keseimbangan politik, definisi kekuasaan, evolusi ideologi politik, ekonomi dan sosial dan seterusnya. Mac Iver (1960) mengemukakan adanya dua jenis hukum dalam kaitannya dengan kekuasaan politik, 
yaitu hukum yang mengemudikan negara yang disebut Konstitusi dan hukum yang digunakan negara untuk memerintah atau disebut hukum biasa (ordinary law). Hukum biasa atau ordinary law merupakan UU yang dihasilkan dari proses politik kompromi antara DPR dan Pemerintah. Oleh karena itu, UU dapat difungsikan sebagai alat politik sepanjang tidak bertentangan dengan hukum konstitusi yang mengemudikan negara. Pendapat tersebut menunjukkan bahwa kebijakan pembangunan tidak lepas dari dinamika politik suatu negara baik dalam proses ratifikasi menjadi produk hukum maupun dalam penerapannya.

\section{Evolusi Kebijakan Perencanaan} Pembangunan Nasional

a. Kebijakan Perencanaan Pembangunan Nasional Era Orde Lama

Pembangunan

institusional

terutama pembentukan suprastruktur politik negara guna menjalankan fungsi-fungsi pemerintahan telah berjalan seiring dengan arah pemerintah dalam menjalankan pembangunan nasional. Kedua hal tersebut berlangsung dalam suasana revolusi mempertahankan kemerdekaan akibat agresi militer Belanda yang mencoba menjajah kembali. Hal ini menyebabkan perhatian pemerintah terbagi antara menghadapi perang dan melangsungkan pembangunan nasional. Karena itu, meski pada tanggal 18 Agustus 1945 telah keluar Maklumat Pemerintah tentang Pembangunan Negara, namun dokumen perencanaan pembangunan nasional pertama yang disebut "Dasar-dasar Pokok Daripada Plan Mengatur Ekonomi Indonesia", dirumuskan setelah pemerintah membentuk Badan Perancang Ekonomi pada 19 Januari 1947 dan Panitia Pemikir Siasat Ekonomi pada 12 April 1947 dimasa pemerintahan Kabinet Sjahrir III. Dokumen tersebut merupakan program pemerintah yang dimaksudkan untuk meningkatkan dan menyebarluaskan secara merata kemakmuran rakyat Indonesia.

Pembentukan Panitia Pemikir Siasat Ekonomi menunjukkan bahwa kebijakan perencanaan pembangunan nasional merupakan proses yang berbasis pada pengetahuan ilmiah. Proses teknokrasi dalam perencanaan pembangunan menjadi mainstream memberi peranan besar pada pemerintah dalam dokumen perencanaan "Garis-Garis Rencana untuk Menyejahterakan Rakyat yang dihasilkan oleh Panitia Pemikir Siasat Ekonomi dan Rencana Kasimo pada periode 1945-1949. Dokumen tersebut berisi rencana program dan penganggaran tiap-tiap departemen kementerian, serta rencana meningkatkan produksi sektor pertanian melalui ekstensifikasi pemanfaatan lahan dan penyediaan bibit unggul dalam jangka waktu tiga tahun untuk mencapai swasembada pangan. Tantangan yang dihadapi pada periode ini adalah belum tertatanya infrastruktur politik baik pemerintah pusat maupun daerah, situasi perang dan pemberontakan, serta instabilitas politik akibat kabinet dalam pemerintahan parlementer yang jatuh bangun (Mustopadidjaja, 2012:31).

Pye (1966) dalam studinya tentang pembangunan politik menjelaskan bahwa stabilitas sosial politik dan perubahan teratur merupakan prasyarat dalam pembangunan ekonomi. Situasi 
politik yang stabil memungkinkan pemerintah untuk berkonsentrasi pada perencanaan dan pelaksanaan dari pada pembangunan yang telah ditetapkan. Namun, stabilitas sosial politik justru menjadi tantangan utama dalam perencanaan pembangunan yang berlangsung dimasa demokrasi liberal dan sistem pemerintahan parlementer. Pilihan sistem politik yang menganut demokrasi liberal menyebabkan kekuatan-kekuatan politik yang terfragmentasi dalam ideologi yang beragam berada dalam hubungan persaingan politik yang tajam dan penuh konflik. Kabinet pemerintahan parlementer berusia sangat singkat dengan periode 1 tahun sebelum terjadi mosi tidak percaya dan pembentukan kabinet baru.

Pada periode 1950-1959, pemerintah berhasil menetapkan dua rencana pembangunan, yakni (Mustopadidjaja, 2013:59): Pertama, Rencana Urgensi Ekonomi atau Rencana Urgensi Industri (19511955). Fokus pemerintah pada periode ini adalah mendorong modernisasi pertanian guna memutus ketergantungan terhadap pasar luar negeri, serta meningkatkan industrialiasi nasional dengan membentuk induk perusahaan nasional dan pendirian pusat pengembangan dan Pendidikan untuk mempercepat industrialisasi. Kebijakan tersebut dipengaruhi oleh perkembangan model pembangunan yang mengkaji tentang kondisi keterbelakangan dan ketergantungan terhadap surplus tenaga kerja di sektor pertanian di negara-negara Eropa Timur dan Tenggara. Rosenstein-Rodan dalam studinya Problems of Industrialisation of Eastern and South-Eastern Europe menggagas tentang perlunya rencana dan program aksi berupa investasi skala besar untuk mempercepat industrialisasi. Hal yang cukup kontras pada periode demokrasi liberal ini, langkah pemerintah untuk memberikan kesempatan pada sektor swasta berkembang, namun juga di sisi lain sekaligus mendorong industri yang dikelola negara melalui kebijakan nasionalisasi industri sektor strategis yang sebelumnya dikuasai asing, terutama perusahaan kolonial Belanda. ${ }^{1}$

Kedua, pada 7 Januari 1952 pemerintah menerbitkan PP No. 2 Tahun 1952 untuk membentuk Dewan Perancang Negara (DPN) yang bertugas mempelajari, menyusun dan menghubungkan rencana-rencana sosial ekonomi, dan Biro Perancang Negara (BPN) yang berfungsi sebagai Badan Pelaksana yang mempersiapkan Rencana Pembangunan Lima Tahunan (RPLT) 1956-1960. RPLT ini baru berhasil disusun saat zaken kabinet di bawah Perdana Menteri Djuanda dan disetujui pada tahun 1958. Namun, masalah pembangunan nasional muncul justru karena faktor politik,

\footnotetext{
1 Kebijakan nasionalisasi digencarkan setelah Presiden Soekarno membentuk Badan Nasionalisasi Badan Nasionalisasi Perusahaan Belanda (BANAS) yang bertanggung jawab langsung di bawah Kabinet dan diberi target untuk menyelesaikan tugasnya hingga tahun 1960. Serangkaian kebijakan nasionalisasi dirilis pemerintah Indonesia untuk berbagai sektor strategis seperti terbitnya UU No. 86 Tahun 1958 tentang Nasionalisasi Perusahaanperusahaan Milik Belanda, PP No. 12 Tahun 1959 tentang Nasionalisasi Peternakan dan Perkebunan, PP No. 18 Tahun 1959 tentang Nasionalisasi Industri Gas dan Listrik, PP No. 13 Tahun 1960 tentang Nasionalisasi Industri Perbankan, PP No. 45 Tahun 1959 tentang Nasionalisasi Industri Maritim, PP No. 50 Tahun 1959 tentang Nasionalisasi Industri Pertambangan
} 
demokrasi liberal yang berlangsung pada 1950-1959 bercirikan seringnya terjadi perubahan kabinet, ketegangan di beberapa daerah, dan kesulitan dalam masalah ekonomi yang menyebabkan pembangunan nasional menjadi tidak berjalan secara efektif. Selain itu, arah dan program pembangunan sangat tergantung pada kabinet dalam pemerintahan parlementer yang berkuasa.

Arah kebijakan pembangunan kembali mengalami perubahan setelah Dekrit Presiden 5 Juli 1959 mengakhiri pemerintahan parlementer dan menghadirkan model demokrasi politik baru yang populer dengan sebutan Demokrasi Terpimpin. Meski di periode ini sistem politik multipartai dan multi ideologi masih dominan, namun tampaknya pembangunan nasional tidak hanya menunjukkan corak yang nasionalistik dimana sektor negara diperkuat, tetapi juga mengadopsi pandangan "Sosialisme ala Indonesia" yang menekankan pada perubahan struktur ekonomi-sosial secara radikal dan mengabaikan peranan modal asing (Mas'oed, 1989:110). Perencanaan pembangunan tunduk pada visi politik presiden sebagaimana dinyatakan dalam Manifesto Politik Republik Indonesia (MANIPOL) dan Undang-Undang Dasar 1945, Sosialisme Indonesia, Demokrasi Terpimpin, Ekonomi Terpimpin, dan Kepribadian Indonesia (USDEK) yang kemudian ditetapkan sebagai Garis-Garis Besar Haluan Negara melalui Tap MPR No. I/MPRS/1960 (Ricklefs, 2005:527).

Guna mentransformasikan GBHN ke dalam kebijakan perencanaan pembangunan, maka dibentuklah Dewan Perancang Nasional (Depernas) yang diketuai oleh $\mathrm{Mr}$.
Muhammad Yamin. Presiden menugaskan Depernas untuk menyusun suatu rancangan rencana pembangunan dengan merujuk pada MANIPOL-USDEK dan menghasilkan dokumen Rencana Pembangunan Nasional Semesta Berencana (RPNSB) yang kemudian ditetapkan melalui TAP No. II/MPRS/1960 menjadi Garis-Garis Besar Pola (Rencana) Pembangunan Nasional Semesta Berencana Tahap Pertama 19611969 (Mutopadidaja, 2013:76). Agar RPNSB dapat segera dilaksanakan, maka MPR kemudian membuat ketetapan No. IV/MPRS/1963 tentang Pedoman Pelaksanaan Garis-Garis Besar Haluan Negara dan Haluan Pembangunan sebagai penjabaran teknis, serta mengintegrasikan Depernas ke dalam kabinet pemerintahan dan merubahnya menjadi Badan Perencanaan Pembangunan Nasional (Bappenas) yang kemudian dibantu tugasnya oleh Musyawarah Pembantu Perencana Nasional (Muppenas).

Secara filosofis, RPNSB tidak lepas dari pengaruh konsep Berdikari dan Ekonomi Terpimpin yang dicanangkan Presiden Soekarno. Hal tersebut merefleksikan pandangan nasionalisme ekonomi sebagaimana dijelaskan oleh List (1841) dimana menekankan pentingnya kebijakan untuk lepas dari ketergantungan modal asing dan menempatkan peranan negara sebagai ujung tombak dalam mewujudkan kesejahteraan masyarakat. Robison (2012:64) menyebutkan bahwa tujuan dari Ekonomi Terpimpin adalah membangun ekonomi industri nasional di sekitar modal negara. Pendekatan Ekonomi Terpimpin menimbulkan keadaan yang dilematis, di satu sisi menjadi entry point bagi kebangkitan sektor negara 
dan swasta pribumi, namun di sisi lain membatasi arus modal asing untuk ikut membiayai pembangunan nasional. Hal ini berdampak pada rendahnya sumber pembiayaan negara, tata kelola anggaran yang timpang dan ketidakprofesionalan dalam pengelolaan industri nasional (BUMN) yang sebagian besar merupakan hasil nasionalisasi.

Sumber pembiayaan sangat tergantung pada hasil rampasan perang dan kompensasi perang dari Jepang, pajak hasil ekspor-impor komoditas dan pendapatan dari industri nasional yang tidak mencukupi. Selain itu, anggaran negara juga banyak tersedot untuk belanja sektor pertahanan dan keamanan yang mencapai lebih dari $50 \%$ anggaran negara, serta belanja pembangunan infrastruktur yang bersifat mercusuar. Sementara itu, BUMN mengalami berbagai masalah manajemen akibat campur tangan politik yang menyebabkan inefisiensi dan kontribusi yang rendah bagi pendapatan negara. Situasi ekonomi yang memburuk ini kemudian berkelindan dengan suhu politik yang meningkat akibat pertentangan politik dan ideologi sehingga menyebabkan program-program strategis dalam RPNSB tidak dapat direalisasikan secara efektif.

\section{b. Dinamika}

\section{Perencanaan Pembangunan Nasional Era Orde Baru.}

Pada tahun 1966-1968, terjadi transisi kebijakan pembangunan nasional dari Orde Lama ke Orde Baru dengan berlakunya Tap MPRS No. XXIII/MPRS/1966 tentang Pembaharuan Kebijakan Landasan Ekonomi, Keuangan dan Pembangunan. Kebijakan baru ini menegaskan bahwa setiap kebijakan pembangunan harus mencerminkan pasal-pasal dalam UUD 1945, berpegang pada azas demokrasi ekonomi, dan dilakukan secara rasional dan realistis (Mustopadidjaja, 2013:125). Kebijakan transisi ini dimaksudkan sebagai langkah stabilisasi dan rehabilitasi dengan prioritas program pengendalian inflasi, pemenuhan kebutuhan pangan dan sandang, rehabilitasi prasarana ekonomi serta peningkatan ekspor. Selain itu, kebijakan transisi ini juga menjadi dasar bagi perencanaan pembangunan lima tahunan yang dimandatkan kepada Bappenas dengan merujuk pada Instruksi Presidium Kabinet No. 15/EK/IN/3/1967.

Bersamaan dengan lahirnya Orde Baru, terjadi perubahan dari kerangka pembangunan nasional Orde Lama yang menekankan sektor negara menjadi lebih akomodatif pada keterlibatan pasar dan investasi asing. Mas'oed (1989:94) menjelaskan bahwa pilihan strategi Orde Baru dengan mengadopsi mekanisme pasar dimaksudkan untuk menarik arus investasi asing, pemulihan dan stabilisasi, serta mendorong pertumbuhan ekonomi nasional. Regulasi untuk memudahkan masuknya modal asing kemudian dirilis dengan UU Penanaman Modal Asing No. 1 Tahun 1967 yang menawarkan berbagai fasilitas kemudahan untuk berbisnis di Indonesia, termasuk insentif perpajakan dan ketentuan tentang Daftar Skala Prioritas (DSP) sebagai instrumen untuk mendapatkan pola investasi jangka panjang yang terbuka untuk modal asing maupun modal dalam negeri (Robison, 2012:143). Kebijakan baru tersebut menganulir Undang-Undang No. 78 Tahun 1958 tentang PMA yang 
membatasi modal asing dalam sektor usaha yang lazim dikerjakan oleh warga negara Indonesia dan jenis perusahaan yang dapat dimasuki. ${ }^{2}$ Strategi ekonomi Orde Baru berhasil meningkatkan investasi asing (foreign direct investment/FDI) yang sebelumnya hanya USD 3 juta pada tahun 1968 menjadi USD 130 juta pada 1970, dan USD 302 juta pada tahun 1972 (Malarangeng, 2002:54). Jumlah proyek yang dibiayai oleh investasi asing pun mengalami peningkatan dimana pada tahun 1967 hanya 13 proyek menjadi 84 proyek pada tahun 1970.

Pendekatan liberal sebagai paradigma dalam pembangunan nasional, terutama sektor ekonomi tidak lepas dari peranan komunitas cendikiawan (epistemic community) dan para teknokrat "Mafia Berkeley" (para ekonom didikan Barat terutama asal University of California di Berkeley) yang dimotori oleh Widjojo Nitisastro dalam kabinet maupun Bappenas. Menurut Anne Booth (2001), masuknya kelompok ini dalam kabinet menandakan bahwa Orde Baru akomodatif terhadap pandangan liberal dan membuka diri atas dukungan Barat (Emerson, 2001:188). Para teknokrat ini pada mulanya menunjukkan sikap pragmatis terhadap ekonomi pasar dan memilih jalan reformasi ekonomi secara hati-hati mengingat Orde Baru juga didukung oleh kelompok nasionalis, terutama dari kalangan

\footnotetext{
${ }^{2}$ Terdapat pembatasan sektor-sektor tertentu, yang mengatur mengenai perusahaan; a. Kereta Api, b. Telekomunikasi, c. Pelayaran dan Penerbangan, d. Pembangkit tenaga listrik, e. Irigasi dan air minum, f. Pabrik mesiu dan senjata, g. Pabrik tenaga atom, $h$. Pertambangan bahan-bahan vital, lihat Undang-Undang No. 78 Tahun 1958 tentang Penanaman Modal Asing.
}

militer yang kritis terhadap isu ideologi, termasuk liberalisme yang mempengaruhi kebijakan strategis pemerintah. Namun, posisi politik kelompok teknokrat liberal ini makin kuat ketika Soeharto memenangkan pemilu tahun 1973 dan memberi ruang bagi dalam pemerintahan kabinet yang baru.

Selama berkuasa, Orde Baru berhasil menetapkan dua produk GBHN yang ditetapkan melalui Tap MPR No.IV/MPR/1973 yang memuat Pola Umum Pembangunan Nasional terdiri dari Pola Dasar Pembangunan Nasional, Pola Umum Pembangunan Jangka Panjang, dan Pola Umum Pembangunan Lima Tahun Kedua yang menjadi dasar bagi pembangunan jangka Panjang tahun 1969-1993, serta GBHN 1993-2019 yang ditetapkan oleh Tap MPR No. II/MPR/1998. GBHN ini kemudian menjadi dasar bagi pemerintah untuk menyusun Rencana Pembangunan Lima Tahunan yang dikenal dengan REPELITA I hingga $X$ yang seluruhannya merupakan tahapan PJP I dan PJP II yang menjadi target pemerintah Orde Baru.

Penetapan GBHN ini memberikan sejumlah makna penting dalam kerangka pembangunan nasional, yakni : pertama, Bappenas menempati posisi yang sangat sentral baik sebagai think tank dalam proses perencanaan maupun eksekutor yang melaksanakan program-program pembangunan yang melibatkan berbagai lembaga negara dan pemerintahan, baik pusat maupun daerah. Proses teknokrasi menjadi penentu dalam rancang bangun kebijakan pembangunan nasional di hulu dan menimbulkan kesan yang menempatkan MPR pada proses hilir sebagai lembaga "stempel" politik untuk mengotorisasi "produk" 
Bappenas menjadi kebijakan negara dalam bentuk Tap MPR. Kedudukan strategis Bappenas ini tidak hanya karena tingginya kepercayaan politik dari Presiden maupun DPR, tetapi juga ditopang oleh keunggulan sumber daya manusia yang terlatih dan terdidik.

Kedua, disusunnya Rencana

Pembangunan Lima Tahunan (Repelita) sebagai tahapan pembangunan nasional yang dimaksudkan untuk mengatasi tantangan pembangunan yang dihadapi, terutama masalah pertumbuhan ekonomi, perubahan struktur dan corak ekonomi, pemerataan pembangunan dan persiapan industrialisasi menuju masyarakat tinggal landas, menunjukkan bahwa model pembangunan teknokratik yang dihasilkan Bappenas memiliki kerangka rujukan teoritik sejalan dengan Rostow tentang Tahapan Pertumbuhan Ekonomi.

Ketiga, selain proses teknokratis, hal yang menarik bahwa Orde Baru memunculkan justifikasi ideologis baru dalam kebijakan pembangunan yang diadopsi dalam GBHN. Hal ini menunjukkan bahwa Orde Baru sebagai suatu rezim politik, di satu sisi memang memberikan peranan besar pada Bappenas, namun di sisi lain klaim Orde Baru sebagai pelaksana Pancasila dan UUD 1945 yang murni dan konsekuen merasa perlu untuk mentransformasikan dalam desain kebijakan pembangunan nasional sebagai basis legitimasi ideologisnya. Hal tersebut dikemas dalam konsep Trilogi Pembangunan sebagai kerangka paradigmatik yang memadukan antara konsep pemerataan pembangunan dan hasil-hasilnya, pertumbuhan ekonomi dan stabilitas nasional yang sehat dan dinamis. Sebagai suatu justifikasi ideologis, konsep Trilogi Pembangunan secara efektif menjadi rujukan bagi setiap kebijakan pembangunan Orde Baru.

Keempat, bahwa GBHN sebagai integrated development planning tidak hanya memadukan program pembangunan antar kementerian dan lembaga negara, baik pusat maupun daerah, tetapi juga menunjukkan adanya visi politik negara baik jangka panjang maupun jangka pendek dalam roadmap dalam pembangunan nasional, serta menjamin aspek kesinambungan antar periode kekuasaan.

Pelaksanaan PJP II yang seharusnya berlangsung hingga tahun 2019 berakhir bersamaan dengan tumbangnya kekuasaan Presiden Soeharto. Kekuasaan Orde Baru yang hegemonik, memunculkan masalah dalam pembangunan nasional, terutama menyangkut maraknya praktek Korupsi, Kolusi dan Nepotisme (KKN), pelanggaran HAM, utang luar negeri, oligarki ekonomi, dan kebijakan ekonomi yang terlalu liberal. Hal ini menjadi triger bagi gerakan protes mahasiswa yang berujung pada ambruknya bangunan politik Orde Baru sekaligus menandai perubahan kerangka pembangunan nasional pasca Orde Baru.

\section{c. Dinamika Kebijakan Perencanaan Pembangunan Nasional Era Reformasi}

Hingga reformasi, Indonesia telah mengalami sejumlah model perencanaan pembangunan nasional sebagaimana dapat dicermati berdasarkan tabel berikut : 
Tabel 1

Evolusi Perencanaan Pembangunan Nasional Indonesia

\begin{tabular}{|c|c|}
\hline Periode & Kebijakan \\
\hline 1945-1949 & Dasar-Dasar Pokok Daripada Plan Mengatur Ekonomi Indonesia \\
\hline 1950-1959 & $\begin{array}{ll}- & \text { Rencana Urgensi Ekonomi } \\
\text { - } & \text { Rencana Pembangunan Lima Tahun (RPLT) }\end{array}$ \\
\hline $1960-1965$ & Rencana Pembangunan Nasional Semesta Berencana \\
\hline 1966-1998 & $\begin{array}{c}\text { Garis-Garis Besar Haluan Negara : } \\
\text { - } \quad \text { PJP (Pembangunan Jangka Panjang } 25 \text { Tahun) } \\
\text { - } \quad \text { Repelita (Rencana Pembangunan Lima Tahunan) } \\
\text { - } \quad \text { Repeta (Rencana Pembangunan Tahunan) }\end{array}$ \\
\hline 1998-2004 & $\begin{array}{l}\text { Pokok-Pokok Reformasi Pembangunan dalam Rangka Penyelamatan dan Normalisasi } \\
\text { Kehidupan Nasional sebagai Haluan Negara }\end{array}$ \\
\hline $2005-2025$ & SPPN dan Rencana Pembangunan Jangka Panjang Nasional (RPJPN) 2005-2025 \\
\hline
\end{tabular}

Sumber : diolah dari Bappenas: Dalam Sejarah Perencanaan Pembangunan Indonesia 1945-2025

Perubahan fundamental terjadi setelah reformasi ketika sejumlah kalangan menilai bahwa tidak adanya GBHN dianggap bahwa Indonesia tidak memiliki pedoman dalam menyelenggarakan pembangunan nasional yang berkelanjutan. Hal tersebut dikaitkan dengan dihapusnya GBHN sebagai konsekuensi amandemen UUD 1945 yang memangkas kewenangan MPR dalam menyusun dan menetapkan GBHN. Padahal, Indonesia telah memiliki kerangka kebijakan perencanaan pembangunan nasional yang baru melalui UU No. 25 Tahun 2004 tentang Sistem Perencanaan Pembangunan Nasional (UU SPPN) dan UU No. 17 Tahun 2007 tentang Rencana Pembangunan Nasional Jangka Panjang 2005-2025 (UU RPJPN).

Undang-Undang SPPN mengatur tentang rencana pembangunan yang akan disusun baik dari segi prosedur penyusunan, pembahasan dan penetapannya hingga menjadi program kebijakan legislasi nasional. Sedangkan UU RPJPN memuat kondisi umum, arahan, tahapan sampai pada prioritas secara konkrit. Oleh karena itu, baik UU SPPN dan UU
RPJPN harus dilihat sebagai suatu kesatuan yang saling melengkapi dan telah menutup peluang inkosistensi secara horizontal dari segi subtansi peraturan. Selain itu, ruang lingkup materi yang diatur jelas, sehingga tidak terjadi pengulangan norma yang telah diatur didalam peraturan perundangan yang mendelegasikan terhadap peraturan pelaksananya (Anggraini, 2015).

Meski tidak sama persis, RPJP dimaksudkan untuk menggantikan fungsi dari pada GBHN yang telah dihapuskan. Meski demikian, terdapat sejumlah perubahan yang mendasar pada RPJP sebagai pedoman dalam pembangunan nasional. Hal tersebut dapat dilihat dari sejumlah aspek, yakni, pertama, untuk menjamin kesinambungan antar periode kekuasaan yang paralel dengan kurun waktu pembangunan nasional jangka menengah lima tahunan, maka setiap calon presiden dan wakil presiden menyusun visi dan misi dengan merujuk pada ketentuan dalam UU RPJPN dan UU SPPN. Ketentuan ini menunjukkan bahwa kekhawatiran terjadinya disharmoni dan diskontinuitas antar periode kekuasaan dalam 
menjalankan roda pembangunan nasional sebenarnya telah diantisipasi oleh UU SPPN dan UU RPJPN.

Kedua, terjadi perubahan pendekatan dalam seluruh rangkaian perencanaan pembangunan dimana UU SPPN menempatkan proses politik sebagai hulu dalam perencanaan pembangunan dan proses teknokratik sebagai hilir dari perencanaan pembangunan nasional lima tahunan. Proses politik ini merupakan peranan dari caprescawapres bersama partai pengusung dalam merumuskan visi, misi dan program pemerintahan lima tahunan ketika terpilih dalam pemilihan presiden. Pada tahap ini penyusunan visi, misi dan program pemerintah meski dapat dipengaruhi oleh platform dan ideologi capres dan cawapres maupun parpol pengusung, namun tetap terikat dengan RPJPN. Sedangkan pada tahap teknokrasi, visi dan misi serta program pemerintahan yang terpilih menjadi input bagi Bappenas untuk melakukan harmonisasi dan sinkronisasi sehingga menjadi produk kebijakan yang disebut dengan RPJMN yang ditetapkan berdasarkan Peraturan Presiden.

Ketiga, mengacu pada pengalaman pelaksanaan PNSB maupun GBHN yang cenderung elitis dan top down, maka SPPN dan RPJPN mengadopsi pendekatan perencanaan yang lebih demokratis hingga penyusunan RPJMN, yaitu politik, teknokratik, partisipatif, top down dan bottom up (Mustopadidjaja, 2012:355). Pendekatan ini sejalan dengan semangat demokratisasi yang membuka keran partisipasi masyarakat dalam proses perencanaan pembangunan. Hal tersebut dilalui pada saat para capres-cawapres dan partai pengusung terlibat dalam interaksi kampanye politik yang memungkinkan terjadinya transaksi gagasan dan kebijakan yang menjadi kehendak masyarakat.

Persoalan yang kemudian sering dipersoalkan pada model yang diadopsi oleh UU SPPN dan UU RPJPN pada umumnya adalah tudingan bahwa model ini tidak menjamin kesinambungan dan terlalu didominasi oleh presiden. Padahal, jika ditelaah lebih jauh secara jelas UU SPPN dan UU RPJPN menegaskan bahwa setiap pemerintahan yang terbentuk melalui pemilu tunduk pada UU tersebut. Selain itu, sering kali dilupakan bahwa terjadi perubahan situasi politik akibat demokratisasi yang makin membuka ruang bagi publik untuk terlibat dalam agenda strategis negara, termasuk untuk berpartisipasi dalam perencanaan pembangunan nasional. Begitu pula dengan peranan partai politik sebagai hulu dari pada kekuasaan, maka proses perumusan visi, misi dan program pemerintahan yang akan diusung oleh caprescawapres semestinya dapat dimanfaatkan sebaik-baiknya oleh parpol untuk memastikan bahwa kebijakan pembangunan yang direncanakan merupakan refleksi dari aspirasi yang berkembang di masyarakat maupun konstituen parpol.

\section{Tantangan dan Skenario Perubahan Kebijakan Pembangunan Nasional}

Sebagaimana dijelaskan oleh Arthur Lewis bahwa perencanaan pembangunan dipengaruhi oleh berbagai faktor seperti kerangka filosofi, kompleksitas politik maupun sistem ekonomi yang berlangsung. Ketiga faktor tersebut menghadirkan 
tantangan nyata dalam perencanaan pembangunan nasional dari masa ke masa. Kebijakan pembangunan ketika diratifikasi menjadi produk hukum berupa UU, maka merupakan ordinary law yang sejak perumusan akan dipengaruhi oleh kepentingan politik faksi-faksi dalam pemerintahan maupun legislatif. Begitu pula pada saat pelaksanaan akan bersinggungan dengan dinamika sosial politik yang berlangsung sebagai bagian dari lingkungan yang melingkupi suatu kebijakan nasional. Ketika Orde Lama berkuasa, fragmentasi politik dan sistem pemerintahan yang berlangsung dalam demokrasi liberal tidak hanya menyebabkan rapuhnya stabilitas politik, akan tetapi juga berdampak pada efektifitas program-program pembangunan nasional. Fragmentasi ideologis dan formasi kabinet parlementer ternyata tidak cukup kuat dan stabil sebagai landasan dalam eksekusi kebijakan pembangunan nasional. Lemahnya tradisi konsensus politik di antara partai politik menyebabkan pemerintah sulit untuk menentukan jenis dan prioritas program pemerintahan. Sedangkan pada aspek ideologi politik, memberikan pengaruh kuat terhadap arah dan strategi kebijakan pembangunan yang dipilih. Praktek Demokrasi Terpimpin pasca berakhirnya demokrasi parlementer diikuti perubahan mainstream pembangunan nasional yang semakin bercorak nasionalistik, state centered dan anti terhadap modal asing dan pasar.

Sementara itu di era Orde Baru pemerintah memberikan ruang yang sangat terbuka bagi pasar dan investasi asing dalam pembangunan nasional. Sedangkan secara politik, keberhasilan Orde Baru melakukan penataan politik guna mewujudkan stabilitas sosial politik telah menghadirkan Golkar sebagai kekuatan dominan. Dukungan mayoritas yang diperoleh Presiden Soeharto telah memungkinkan pemerintahannya menyusun suatu kebijakan perencanaan pembangunan yang jauh lebih efektif dan merealisasikannya tanpa hambatan politik yang signifikan. Hal tersebut ditambah dengan pendekatan pemerintahan yang otokratis, sentralistik serta didukung oleh mesin birokrasi politik yang kuat menjadi landasan dalam perencanaan dan pelaksanaan pembangunan nasional.

Situasi jauh berbeda berlangsung setelah reformasi. Terjadi perubahan politik yang besar akibat demokratisasi dalam sistem politik.

Kehidupan kepartaian telah berubah tanpa adanya partai mayoritas mutlak yang mendapat dukungan dan privellege dari pemerintah. Sistem multipartai ini mendorong terjadinya konsensus politik atas berbagai kebijakan, termasuk dalam hal kebijakan perencanaan pembangunan. Sementara itu, penerapan desentralisasi melalui pembentukan daerah otonom juga berdampak pada kerumitan sistem perencanaan pembangunan yang memberi ruang tidak hanya pada masyarakat saja, tetapi juga menyangkut kepentingan daerah yang harus diakomodasi dan disinkronisasi dengan kepentingan antar daerah dan pusat. Rumitnya mengintegrasikan pembangunan pusat dan daerah sesungguhnya dapat dipahami, namun hal tersebut tidak semata-mata karena ketiadaan GBHN namun juga konsekuensi dari penerapan desentralisasi 
pemerintahan yang menyebabkan hubungan pusat dan daerah tidak lagi bersifat monosentris, melainkan polisentris dan bergerak dari satu kontinum ke kontinum lainnya, baik dalam kerangka negara federal maupun negara kesatuan (Umbach, 2002; Prasojo, 2015:1.5). Kerumitan inilah yang menurut Syamsuddin Haris (2007) memerlukan penataan hubungan pusat dan daerah dengan bersandar pada kemitraan dan saling ketergantungan. Dengan demikian, evolusi kebijakan perencanaan pembangunan nasional tidak dapat dipisahkan dari perkembangan masyarakat yang demikian pesat. Perencanaan pembangunan membantu setiap negara untuk membuat proyeksi tentang alokasi sumber daya serta tujuan masa depan yang hendak dicapai, namun hal tersebut tidak dapat dipisahkan dari konteks perkembangan masyarakatnya.

Perubahan dalam masyarakat tentu harus direspon dengan mempersiapkan skenario perubahan model kebijakan yang dapat dipilih. Terkait dengan hal tersebut, setidaknya ada beberapa opsi yang dapat dipertimbangkan antara lain : pertama, mempertahankan model kebijakan perencanaan pembangunan sebagaimana diadopsi dalam UU SPPN dan UU RPJPN dengan menekankan pada efektifitas proses perencanaan politik di hulu yang melibatkan peranan parpol pengusung dan capres-cawapres sehingga visi dan misi merefleksikan kehendak masyarakat sekaligus linkage dengan RPJPN yang merupakan induk dari perencanaan pembangunan nasional. Selama ini, perumusan visi dan misi caprescawapres seringkali hanya dianggap pelengkap administratif belaka dalam proses pencalonan pasangan caprescawapres. Padahal, visi dan misi merupakan input utama dalam perumusan RPJMN yang akan dijadikan acuan oleh pemerintah selama lima tahun. Sehingga, perlu dipertimbangkan mekanisme untuk keterlibatan DPR dalam perumusan RPJMN yang selama ini menjadi domain Presiden dan Bappenas. Hal ini dimaksudkan agar RPJMN dapat terintegrasi dengan fungsi politik DPR sebagai wakil rakyat dalam mengartikulasikan aspirasi masyarakat.

Kedua, menetapkan kembali model GBHN atau sebutan lainnya dengan konsekuensi perubahan struktur ketatanegaraan dan hukum di Indonesia. Menghidupkan kembali GBHN tentu tidak semudah an sich mengembalikan kewenangan MPR melalui amandemen UUD NRI. Jika GBHN dihidupkan kembali, perlu dipertimbangkan apakah kedudukan MPR akan menjadi supreme body karena memiliki kewenangan menghasilkan produk hukum yang mengikat seluruh cabang-cabang kekuasaan negara atau hanya sekedar menghasilkan dokumen perencanaan pembangunan yang tidak berkonsekuensi secara politis maupun yuridis dalam hal pelaksanaanya. Persoalan itu tentu akan menjadi kompleks jika dikaitkan dengan hulu yang akan menjadi input dalam proses perencanaan. Jika inputnya berasal dari Bappenas dan MPR yang menetapkan, maka hal ini akan mengulang model teknokratis yang terjadi dimasa orde Baru. Namun, jika MPR yang merumuskan dan menetapkan, maka tentu MPR perlu memiliki sumber daya yang memadai untuk membuat suatu rumusan perencanaan yang holistik dan integratif atas semua cabang 
kekuasaan negara. Selain itu, model ini juga perlu mempertimbangkan komitemen politik dalam amandemen UUD 1945 sebelumnya yang dimaksudkan untuk memperkuat sistem pemerintahan presidensial. Peranan presiden yang demikian besar dalam perencanaan pembangunan memang merupakan konsekuensi yang terjadi akibat sistem presidensial yang menempatkan presiden sebagai kepala pemerintahan dan kepala negara yang dipilih langsung oleh masyarakat.

Ketiga, mengadopsi pendekatan lain dimana Pokok Haluan Negara sebagai program strategis negara yang bersifat makro, jangka panjang dan mengikat seluruh cabang kekuasaan negara diadopsi dalam batang tubuh dari suatu konstitusi. Model perencanaan pembangunan seperti ini dipraktekkan oleh sejumlah negara dengan Directive Principles of State Policy (DPSP) sebagaimana diadopsi dalam Konstitusi India, Directive Principles of Social policy yang dianut dalam Konstitusi Irlandia (Jacob, 2005). Hal tersebut memuat kewajibankewajiban fundamental negara terutama menyangkut keadilan sosial, kesejahteraan ekonomi, kebijakan luar negeri dan masalah terkait administrasi pemerintahan. Model tersebut menempatkan agenda pemerintahan strategis dalam pembangunan nasional sebagai mandat konstitusional yang harus dijalankan. Model ini tidak menghasilkan dokumen hukum perencanaan yang terpisah dan menghadirkan suatu kelembagaan politik baru. Namun, konsekuensinya maka jika dipandang perlu, sebuah Konstitusi harus ditempat dalam posisi yang terbuka untuk dilakukan amandemen guna melakukan penyesuaian dengan perkembangan masyarakat.

\section{Kesimpulan}

Evolusi kebijakan perencanaan pembangunan nasional menunjukkan bagaimana pengaruh faktor filosofi, politik dan ekonomi terhadap perencanaan dan pelaksanaan pembangunan nasional dari masa ke masa. Haluan politik negara menentukan proses politik di hulu dalam perencanaan pembangunan dan mempengaruhi derajat keterlibatan birokrasi perencana dalam proses teknokrasi di hilir. Pada masa Presiden Soekarno memimpin, perencanaan pembangunan nasional merupakan operasionalisasi dari pada visi politik negara dan menentukan proses teknokrasi. Sedangkan pada masa Presiden Soeharto perencanaan pembangunan lebih banyak ditentukan oleh proses teknokrasi dari birokrasi perencana pembangunan. Hal ini menunjukkan pengaruh ilmu pengetahuan yang lebih dominan dibandingkan pendekatan yang bersifat politik. Sementara itu, model perencanan pembangunan nasional pasca reformasi menekankan sinergi antar proses politik di hulu dengan proses teknokrasi di hilir. Kedua proses tersebut harus dimaknai sebagai suatu yang integral dan saling mempengaruhi sebagai tahapan dalam perencanaan pembangunan nasional.

Sementara itu, gagasan tentang perlunya model baru dalam perencanaan pembangunan nasional harus dikaitkan dengan perkembangan objektif dalam masyarakat dan kebutuhan untuk 
merealisasikan ide dan cita-cita masyarakat sebagaimana dinyatakan dalam Konstitusi. Opsi-opsi yang dapat ditempuh semestinya dibuka luas dengan pendekatan berbasis pengetahuan dan menimbang empirisme di berbagai negara mengenai model kebijakan perencanaan pembangunan nasionalnya, serta belajar dari empirisme Indonesia dengan berbagai pendekatan yang telah diadopsi. Setidaknya, faktor-faktor argumentasi yang bersifat filosofis, politis maupun ekonomis yang mempengaruhi model kebijakan perencanaan pembangunan nasional menjadi instrumen untuk menemukan model yang paling tepat bagi Indonesia dimasa depan.

\section{Referensi}

Buku :

Ayal, B.B. \& Jacob, (2005). A. Indian History, World Developments and Civics.

Hettne, Bjorn. (1991). Development Theory and the Three World, Essex: Longman Scientific and Technical.

Lev, Daniel. (1990). Hukum dan Politik di Indonesia; Kesinambungan dan Perubahan, Jakarta: LP3ES.

Emmerson, Donald, K. (2001). Indonesia Beyond Soeharto; Negara, Ekonomi, Masyarakat, Transisi. Jakarta: The Asia Foundation \& Gramedia Pustaka.

Eko Parsojo dkk, (2015). Pemerintahan Daerah, Jakarta: Universitas Terbuka.

List, Friederich (1841). The National System of Political Economy. London: Longman, Green and Co.

Pye, Lucyan W. (1960). Aspects of Political Development, Boston:
Little Brown and Company.

Iver, Mac (1960). The Modern State, Oxford: University Press.

Umbach, Maiken (2002). German Federalism: Past, Present Future, New York: Palgrave.

Mas'oed, Mochtar, (1989). Stabilisasi dan Pembangunan Ekonomi yang Berorientasi Keluar, dalam Ekonomi dan Struktur Politik Orde Baru 1966-1971. Jakarta: LP3ES.

Ricklefs, Mc. (2005). Sejarah Indonesia Modern, 1200-2004, Jakarta: Serambi.

Budiarjo,Miriam. (2007). Dasar-Dasar Ilmu Politik, Jakarta: Gramedia Pustaka.

Mustopadidjaja Ar, dkk,(2012). BAPPENAS: Dalam Sejarah Perencanaan Pembangunan Indonesia 1945-2025, Jakarta: LP3ES \& Paguyuban Alumni Bappenas.

Healey, Patsy. (1997). Collaborative Planning Shaping Places in Fragmented Societies, London: Macmillan Press.

Robison, Richard. (2021). Soeharto dan Bangkitnya Kapitalisme Indonesia, Jakarta: Komunitas Bambu.

Haris, Syamsuddin (ed). (2007). Desentralisasi dan Otonomi Daerah (Desentralisasi, Demokratisasi dan Akuntabilitas Pemerintahan Daerah), Jakarta: LIPI Press.

Meyer, Thomas. (2009). Demokrasi; Sebuah Pengantar untuk Penerapan, Jakarta: Friedrich Ebert Stifung, Jakarta.

Lewis, W. Arthur. (1951). The Principles of Economic Planning: A Study Prepared for The Fabian Society, Washington: Public Affairs Press.

Rostow, WW. (1963). The Stages of 


\section{Jurnal :}

Economic Growth: A NonCommunist Manifesto, London: University Press.

Anggraini, Yessi. (2015), Perbandingan Perencanaan Pembangunan Nasional Sebelum dan Sesudah Amandemen Undang-Undang Dasar 1945, Fiat Justisia Jurnal Ilmu Hukum Volume 9 No. 1, Januari-Maret 2015.

Huff, W. (1995). The Developmental State, Government, and Singapore's Economic Development Since 1960. World Development, 23, 1421-1438.

Isseman, Andrew, M. State Economic Development Policy and Practice in the United States: A Survey Article, 1993, dalam https://journals.sagepub.com/d oi/10.1177/0160017694016001 04, diakses 18 Agustus 2021.

\section{Internet :}

Bivitri Susanti dalam Badan Pengkajian MPR Tindaklanjuti Rekomendasi Amandemen UUD 1945,

https://www.hukumonline.com/ berita/baca/lt5d9f1b8aa7b44/b adan-pengkajian-mprtindaklanjuti-rekomendasiamandemen-uud-1945?page $=$ all, diakses 19 Agustus 2021.

Ide Kembalikan GBHN: Enggak Relevan \& Cuma Manuver Tekan Presiden dalam https://tirto.id/ide-kembalikangbhn-enggak-relevan-cumamanuver-tekan-presiden-chlD, diakses tanggal 19 Agustus 2021. Jimly Sebut Indonesia Rumit hingga Perlu Hidupkan Kembali GBHN, https://www.viva.co.id/berita/n asional/1242119-jimly-sebutindonesia-rumit-hingga-perlu- hidupkan-kembali-gbhn, diakses 18 Agustus 2021.

Kritik Demokrasi Indonesia, Megawati Sebut seperti "Pocopoco",

dalam https://nasional.kompas.c om/read/2016/01/10/1605356 1/Kritik.Demokrasi.Indonesia.M egawati.Sebut.seperti.Pocopoco. Diakses 18 Agustus 2021.

Temui Jokowi, Ketua MPR Sebut Presiden Setuju Amendemen UUD 1945 Hanya untuk PPHN, dalam

https://nasional.kompas.com/re ad/2021/08/14/14580071/tem ui-jokowi-ketua-mpr-sebutpresiden-setuju-amendemenuud-1945-hanya-untuk, diakses 17 Agustus 2021. 